\title{
A AEQUITAS E A APLICAÇÃO DO DIREITO EM ROMA
}

AEQUITAS AND LAW ENFORCEMENT IN ROME

Maria Cristina Carmignani*

\begin{abstract}
Resumo:
O presente trabalho tem por objetivo o estudo das atividades desenvolvidas pelos pretores - magistrado judiciários romanos - dentro do processo formulário que, inspirados na aequitas, corrigiram as injustiças do ius civile, aproximando-o do bonum-aequm.

Palavra-chave: Aequitas. Ius civile. Bonum-aequm. Direito Romano.
\end{abstract}

\begin{abstract}
:
This work aims to the study of the activities developed by Roman praetors - judicial magistrates - within the formulary procedure that inspired aequitas, correcting the injustices of the ius civile, linking it to the bonum-aequm.
\end{abstract}

Keywords: Aequitas. Ius civile. Bonum-aequm. Roman Law.

1. A eqüidade aristotélica e a justiça distributiva

O cerne deste trabalho reside na discussão a respeito de uma das maiores dificuldades na aplicação da lei, em razão de sua generalidade: estabelecer regras que sejam adequadas a todas as situações práticas, com suas especificidades.

Essa dificuldade foi percebida por Platão, ao afirmar que "jamais uma lei será capaz de estabelecer com exatidão o melhor e o mais justo a todos simultaneamente. Na verdade, entre os homens, como entre os atos, há dessemelhanças, além de que nenhuma coisa humana é imutável, o que não permite a nenhuma arte, seja ela qual for, formular nenhum princípio cuja simplicidade valha para toda uma matéria, sobre todos os pontos, sem exceção, e para todos os tempos". ${ }^{1}$

Aristóteles foi além da mera constatação, trazendo a resposta para essa questão, por meio da noção grega da equidade (epieikeia), e daquilo que é équo (tò epieikès).

Segundo Aristóteles, o eqüitativo, embora seja melhor que uma simples idéia de justiça, é em si mesmo justo, e não é por ser especificamente diferente da justiça

Professora Doutora de História do Direito da Faculdade de Direito da Universidade de São Paulo. Advogada.

1 PLATÃO. O político. Trad. Jorge Daleikat e João Cruz Costa. São Paulo: Abril Cultural, 1991. (Os Pensadores). 
que ele é melhor do que o justo. A justiça e a eqüidade são, portanto a mesma coisa, embora a equidade seja melhor. ${ }^{2}$

Esclarece Aristóteles que o eqüitativo é o justo, mas não o justo segundo a lei, e sim um corretivo da justiça legal, uma vez que toda lei é de ordem geral, não sendo possível que seja correta em relação a certos casos particulares. ${ }^{3}$

Desta forma, conclui que o eqüitativo é justo, e melhor que uma simples justiça, sendo, por natureza, uma correção da lei onde esta é omissa devido à sua generalidade. ${ }^{4}$

Assim, como demonstra Aristóteles, o direito necessita do suplemento da equidade (epieikeia), do justo que vai além da lei escrita, assegurando-lhe uma maior flexibilidade, ditando regras até mesmo contrárias ao ordenamento, mas que resultem na efetiva aplicação da justiça.

Nesse sentido, a equidade seria a medida corretiva da justiça legal quando esta engendra a injustiça pela generalidade de seus preceitos normativos. ${ }^{5}$ Seria, portanto, a justiça por natureza, e não a justiça política, regida pela lei, ${ }^{6}$ sendo superior a esta.

Desta forma, como já preconizava Aristóteles, deveria existir alguém, ou algum poder, que pudesse aplicar a epieikeia, como suplemento do direito, para corrigir suas omissões e injustiças. ${ }^{7}$

Aristóteles ${ }^{8}$ revela a incapacidade da lei de, por si só, abranger todas as questões - o justo universal - razão pela qual seria necessário o magistrado, que deveria julgar conforme o melhor de seu juízo, dada a peculiaridade dos casos, que a lei não poderia alcançar.

A eqüidade aristotélica, como forma de adaptação da generalidade das normas jurídicas aos casos concretos, tipifica exatamente a atividade judicial, na qual o juiz é titular da aplicação da justiça corretiva, atribuindo as pessoas o que é justo. ${ }^{9}$

Assim, segundo o mesmo filósofo, o juiz é o instrumento para aplicação da aequitas, fazendo-a atuar em um caso concreto, em razão da abstração da lei. ${ }^{10}$

\footnotetext{
ARISTÓTELES. Ética à Nicomaco. Madrid: Instituto de Estudos Políticos, 1970. 1137 b, 10.

Id. Ibid.

Id. Ibid.

Id. Ibid.

6 Ver, nesse sentido, a diferença entre justo no sentido irrestrito e o justo no sentido político. ARISTÓTELES. Ética. a Nicômaco, cit., V, 1.134, b.

7 ARISTÓTELES. Ética a Nicômaco, cit., V, 1.137, b, 10.

8 ARISTÓTELES. A política, III, 16, 1287 a 20-27.

9 A respeito da justiça corretiva, ver também Aristóteles. Ética a Nicômacos, cit., V, 1132, a.

10 ARISTÓTELES. Ética a Niicômaco, cit., V, 3,1129b30 e 14,1137b19-23.
} 
É este aspecto, precisamente, que será objeto de análise nos capítulos subseqüentes uma vez que do juiz, no momento de realizar a justiça corretiva, espera-se que, como justiça viva, ${ }^{11}$ atribua o justo.

Mas, indaga-se, o que é o justo? Seria o justo legal, a simples aplicação da lei?

Pelo conceito aristotélico de justiça, o justo seria o ideal almejado pela sociedade naquele momento, a ser aplicado diante das especificidades daquela situação fática, procurando assim alcançar a justiça por natureza, a epieikeia, o justo ideal, em contraposição muitas vezes ao denominado "justo convencional”, ou seja, o justo conforme a Lei.

A equidade aristotélica seria a revelação do justo em concreto, como preceito básico do direito e o "homem justo, em Aristóteles, é, com efeito, o que é apto a executar, por escolha deliberada, ações justas, meio de equilibrio entre dois extremos racionalmente determinados (É. N., V, 9,1134a). A atualização desse meio não pode ser determinada a priori, de uma só vez, mas se identifica com uma atividade perpétua, sempre renovada, a cada caso concreto". ${ }^{12}$

\subsection{A Aequitas no Direito Romano}

A partir da dominação romana na magna Grécia - o que os fez herdeiros do legado helênico - os romanos foram influenciados pela epieikeia grega, acima descrita, a que denominaram de aequitas, passando assim a formular novas regras jurídicas, inspirados nesse justo ideal.

Por esta razão, os romanos não chamavam o Direito de "direito", chamavamno de "jus", ou justo, exatamente porque o Direito não é a lei, o Direito é o justo, o justo natural. ${ }^{13}$

Encontramos nas fontes romanas a famosa definição de jus, dada pelo jurisconsulto Celso (D.1.1.1, pr.), que exprime a essência do Direito para os romanos: ius est ars boni et aequi.

Dentre as várias posições da doutrina a respeito do significado dessa definição, ${ }^{14}$ destacamos a de Biondi ${ }^{15}$ no sentido de que os romanos não se preocupavam em definir o direito por suas características formais, mas sim pela sua própria substância:

\section{$O$ direito é a arte do bem e do justo.}

\footnotetext{
1 ARISTÓTELES. Ética a Niicômaco, cit., V, 3,1129b30 e 14,1137b19-23.

12 Cf. FERRAZ JÚNIOR, Tércio Sampaio. Estudos de filosofia do direito. 2. ed. São Paulo: Atlas, 2003. p. 206.

13 TELLES JÚNIOR, Goffredo. Iniciação na ciência do direito. Ed. Saraiva. São Paulo, 2001. p. 359-363.

14 A respeito das várias posições da doutrina ver, por todos, RICCOBONO, Salvatore. Lineamenti delle storia delle fonti e del diritto romano. Milano: Giuffrè, 1949. p. 122 e ss.

15 BIONDI, Biondo Istituzioni di diritto romano. 2. ed. rev. e ampl. Milano: Giuffré, 1952. p. 60-61.
} 
Desta forma, para indicar o objeto e a essência do direito, os romanos utilizavam-se do termo AEQUITAS (aequi) que não correspondia a um conceito absoluto e imutável, estando vinculado diretamente ao momento social.

Ainda segundo Biondi, ${ }^{16}$ a aequitas seria a justiça do caso concreto: é pois entidade extremamente variável que impede o enrijecer do direito em uma fórmula definitiva. A aequitas tende a traduzir-se no ius; nela se inspiram o legislador, os juristas ao apresentarem sua doutrina, os magistrados na sua atividade.

Para Bonfante, ${ }^{17}$ o termo aequitas significa igualdade - princípio informador do direito - que, muitas vezes, não correspondia à norma jurídica, surgindo, então, a antítese entre ius e iustum, ou aequum.

Desta forma, a expressão Aequitas, objetivamente, identificar-se-ia com os termos modernos - JUSTIÇA e JUSTO - no sentido de JUSTIÇA IDEAL, princípio supremo inspirador do direito universal. ${ }^{18}$

Por esta razão, o sentido da Aequitas não foi sempre o mesmo em Roma, variando de acordo com a concepção social de cada época, como acentua Moreira Alves: ${ }^{19}$ no período clássico, tem o sentido moderno de justiça, de direito justo; no pós-clássico, toma o aspecto de benevolência, caridade, ocasião em que os imperadores derrogavam leis e princípios para, por exemplo, favorecerem humildes.

Segundo Ebert Chamoun, ${ }^{20}$ "no direito justinianeu o domínio da equidade é diverso. Extinta a diferença entre o ius civile e o ius honorarium, a aequitas aparece bafejada pelos ideais cristãos de humanitas, benignitas, benevolentia , pietas, caritas, têrmos que freqüentemente a designam.

Na época clássica, no entanto, a aequitas é considerada como expressão da ratio naturalis - da justiça ideal - passando a veículo através do qual se iniciou o abrandamento do rigorismo excessivo do ius civile, tida até mesmo como fonte suprema do direito. (Cícero, Topica, 2, 23).

Desta forma, os romanos levavam em conta, para a solução de cada caso, em concreto, não a aplicação pura e simples do ius civile, mas, sim, da aequitas, que era invocada constantemente, mesmo contra legem. (Cícero, Orat., I.56.240).

BIONDI, Biondo. Istituzioni di diritto romano, cit., p. 60-61.

17 Cf.: BONFANTE, Pietro. Instituciones de derecho romano. 8. ed. Madrid: Instituto Editorial Reus, 1934. p. 7-8.

18 Ver PORCHAT, Reynaldo. demonstrando a identificação, em vários textos romanos, da justitia e da aequitas. in Curso elementar de direito romano. 2. ed. São Paulo: Melhoramentos, 1937. p. 131 e ss.

19 Cf. ALVES, José Carlos Moreira. Direito romano. 13. ed. Rio de Janeiro: Forense, 2003. v. 1, p. 78.

20 CHAMOUN, Ebert. Instituições de direito romano. 3. ed. rev. e aum. Rio de Janeiro: Forense, 1957. p. 34. 
Foi inspirado neste princípio que os jurisconsultos, e notadamente os magistrados romanos, livraram esse direito escrito - considerado odioso pela sociedade, como atesta Gaio $^{21}$ - de suas amarras, procurando aproximá-lo do bonum-aequm.

\subsection{A atividade criadora dos pretores}

\subsubsection{A magistratura judiciária}

O processo romano no período arcaico desenvolvia-se perante uma única figura, o rex, que detinha todos os poderes, inclusive de julgar. Com o desenvolvimento de Roma, os litígios passaram a ser mais complexos e numerosos, exigindo a criação de magistraturas públicas, com funções específicas jurisdicionais.

Isso ocorre nas últimas décadas da monarquia, consolidando-se com a constituição da República romana, representada na figura dos Pretores. ${ }^{22}$

Os pretores eram magistrados que exerciam função judiciária pelo período de um ano, dividindo-se em urbanos e peregrinos. ${ }^{23}$ Todos os magistrados romanos tinham a faculdade de promulgar editos - proclamação oral de seu programa, elaborado no início de seu mandato - que era escrito em uma tábua pintada de branco, chamada de álbum. ${ }^{24}$

Nesse álbum o magistrado judiciário procedia a um verdadeiro inventário de todos os meios que um particular poderia utilizar para exercer o seu direito, nele relacionando os meios de proteção judicial (ações) decorrentes do ius civile. ${ }^{25}$

Não-obstante os pretores fossem magistrados judiciários, dadas às peculiaridades do processo civil romano das épocas pré-clássica e clássica, inseridos no sistema da ordo iudiciorum privatorum, ${ }^{26}$ estes não tinham como atribuição julgar, mas

${ }_{21}$ GAIO (I., 4.30) noticia que as ações da lei - tipo de processo que existia no período arcaico romano, extremamente formal, caracterizado por gestos e palavras rituais, marcado por aspectos religiosos - com o passar do tempo passaram a ser odiadas, em razão de seu rigor excessivo, o mesmo podendo ser dito com relação ao ius civile vetus, superado e também reprovado pela sociedade mais evoluída da época.

22 Cf. TUCCI, José Rogério Cruz e; AZEVEDO, Luiz Carlos de. Lições de história do processo civil romano. São Paulo: Ed. Revista dos Tribunais, 1996. p. 41-45.

23 O Pretor urbano cuidava de litígios entre cidadãos romanos e o peregrino cuidava de litígios em que uma das partes fosse estrangeira.

24 Cf. ALVES, José Carlos Moreira. Curso de direito romano, cit., v. 1, p. 22-23.

25 O ius civile era o Direito Romano antigo, aplicável apenas aos cidadãos romanos.

26 O sistema de organização da instância no período das legis actiones e formulário eram do ordo iudiciorum privatorum - ordem dos juízos privados - bifásico, que se desenrolava inicialmente perante o pretor, na fase in iure, incumbido de organizar e fixar os termos da controvérsia e, após, na fase apud iudicem, perante o iudex, um particular escolhido pelas partes, que tomava conhecimento do litígio, determinava a produção das provas e julgava. O processo civil romano somente torna-se totalmente público no Dominato, com o progressivo desenvolvimento da cognitio extra ordinem do princeps, adotado para àquelas situações não amparadas pela jurisdição ordinária, processo este que se desenvolvia perante uma única autoridade estatal, denominado de cognitio extra ordinem. 
apenas e tão somente organizar a controvérsia entre as partes e remete-las ao iudex, árbitro privado incumbido do julgamento.

Isto se dava em razão de o procedimento ser dividido em fases, atuando o pretor apenas na primeira delas, denominada in iure, devendo limitar-se à indicação da solução a ser adotada, ou seja, declarar quais as normas jurídicas pertinentes ao caso concreto - fundadas no ius civile - o que simbolizava a iurisdictio em Roma: ${ }^{27}$ dizer o direito.

Desta forma, a iurisdictio romana atribuía ao magistrado o poder de organizar a controvérsia, concedendo ou não uma ação, permitindo ou não que fosse dada seqüência aos atos procedimentais que levariam à decisão da controvérsia, cuja sentença seria dada na $2^{\mathrm{a}}$ fase do processo, pelo iudex - árbitro privado escolhido pelas partes - fase esta denominada apud iudicem.

Somente no período pós-clássico é que a iurisdictio passa, tal como modernamente, a fazer parte do poder público de julgar e dar execução ao julgado (D. II, Tit. I), em razão da oficialização do último sistema processual civil em Roma, que era um procedimento de direito imperial - da cognitio extra ordinem - quando então a instância passa a desenrolar-se perante um único juiz, funcionário do Estado.

\subsubsection{O Edito dos pretores e a Aequitas}

No período arcaico de Roma vigorava o procedimento das ações da lei - legis actiones - extremamente rigoroso e excessivamente formalista, que deixava de resolver muitas controvérsias, uma vez que somente poderiam ser concedidas ações pelos pretores naquelas situações expressamente previstas no vetusto ius civile.

Nesse processo, considerava-se titular da actio, não qualquer cidadão que preenchesse certos requisitos, mas, somente, aquele que lograsse demonstrar, nos esquemas preestabelecidos, uma situação de direito material realmente existente. ${ }^{28}$

Assim, o que havia era um sistema de ações, sendo que estas deveriam estar de acordo com as palavras escritas nas leis, ou terem sido por estas criadas, motivo pelo qual eram imutáveis (Gaio, I., 4.11 e 30).

Desta maneira, fora daquelas situações expressamente previstas no ius civile, não havia uma ação que pudesse assegurar em Roma a tutela de todo e qualquer direito subjetivo lesado.

\footnotetext{
27 A respeito da extensão e natureza da iurisdictio no direito romano, ver VOLTERRA, Eduardo. Instituciones de derecho privado romano. Madrid: Civitas, 1991. p. 214-215.

28 TUCCI, José Rogério Cruz e; AZEVEDO, Luiz Carlos de. Lições de história do processo civil romano, cit., p. 45.
} 
Por esta razão, como noticia Gaio (I., 4.30), esse tipo de procedimento tornou-se odioso para a sociedade mais evoluída da época e acabou sendo abolido pela Lei Ebúcia e pelas duas Leis Júlias, levando os processos a se realizarem por palavras fixas, i.e., por fórmulas, o que foi denominado processo formulário. ${ }^{29}$

A partir da introdução do processo formulário, ${ }^{30}$ os iudicia privata sofrem uma grande transformação em Roma, passando os pretores a desenvolver um papel de suma importância dentro do processo, não mais se limitando à mera e automática aplicação da lei.

Isto se dá em razão de ser este um processo menos rígido, fundado em fórmulas que correspondiam ao esquema abstrato contido no edito do pretor, adaptado ao caso concreto, e redigido em um documento pelo magistrado, com o auxílio das partes, fixando-se o objeto da demanda que seria julgada pelo iudex, na $2^{\text {a }}$ fase do processo.

O novo processo instaurado também estava inserido no sistema do ordo iudiciorum privatorum, sendo, portanto, bifásico. No entanto, era bem menos formalista e mais rápido, parcialmente escrito, desenvolvendo-se sempre segundo um rito padrão - ao contrário do processo per legis actiones, que possuía formas específicas de ação.

Dentro desse contexto, os pretores, procurando adequar o ordenamento jurídico aos novos valores sociais da época clássica, criaram um direito mais moderno e eficiente do que o ius civile antigo, e o fizeram inspirados na aequitas romana, ${ }^{31}$ livrando o direito de suas amarras, procurando aproximá-lo do bonum-aequm, como já fizemos notar.

Os Pretores passaram, gradativamente, a construir uma verdadeira ciência do direito, uma vez que formulavam novas regras - inspiradas nesse ideal de justiça - que eram introduzidas nos seus editos e aplicadas dentro do processo formulário, corrigindo, suprindo ou afastando a aplicação do ius civile, quando iníquo. ${ }^{32}$

Com base nesse princípio supremo, os magistrados levavam em conta para a solução de cada caso em concreto, não apenas a aplicação pura e simples do ius civile, mas sim da aequitas, que era invocada constantemente, mesmo contra legem. (Cícero,

${ }_{29}$ Segundo José Rogério Cruz e Tucci e Luiz Carlos de Azevedo, Fórmula, diminutivo de forma, é palavra grega que significa modelo. Fórmula, portanto, é um autêntico modelo abstrato pelo qual se propiciar litigar por escrito, em conformidade com os esquemas jurisdicionais previstos, pelo direito honorário, no edito do pretor. In Lições de história do processo civil romano, cit., p. 74.

30 Quanto à introdução desse novo tipo de procedimento, encontramos várias teses a respeito; ver, por todos, ALVES, José Carlos Moreira. Curso de direito romano, cit., v. 1, p. 206-207.

31 Cf. Bonfante, a aequitas seria o princípio informador do direito que, muitas vezes não correspondia à norma jurídica, surgindo, então, a antítese entre ius e iustum, ou aequum, In Instituciones de derecho romano, cit., p. $7-8$.

32 Cf. BONFANTE, Pedro. Instituciones de derecho romano, cit., p. 22-23. 
Orat., I.56.240) - como destacado no capítulo 2, item 2.2., supra - exprimindo a essência do Direito para os romanos: ius est ars boni et aequi. (D.1.1.1, pr.).

Assim, quando se apresentava um litígio, se a mera aplicação das leges ou das regras rituais do ius civile levasse a uma solução "iníqua" (in-aequa), então o pretor corrigia esse direito, pela aplicação da aequitas, veículo utilizado para o abrandamento do rigorismo excessivo do Direito Romano antigo.

Para que a decisão refletisse a aequitas, o pretor assinalava na fórmula quais os elementos que deveriam ser valorados pelo iudex, ampliando, para tanto, cada vez mais, por meio de seus editos, as normas e os meios processuais ordinários e extraordinários de que poderia se servir na administração da justiça, para que pudesse atingir esse escopo. ${ }^{33}$

Invocando esse princípio inspirador do direito, e investidos da iurisdictio, os pretores deram origem ao denominado "direito honorário"34 - que era um sistema de ações e não um sistema de direitos - concedendo, ou não, uma actio ou uma exceptio, ${ }^{35}$ procedendo à correção das injustiças do ius civile, conforme nos indicam as fontes, em busca do ideal ético que existe, em estado amorfo, na consciência social, e que tende a transformar-se em direito positivo: ${ }^{36}$

\section{Ius praetorium est, quod praetores introduxerunt adiuvandi vel supplendi vel corrigendi iuris civilis gratia propter utilitatem publicam. (D,1,1,7,1 Papin.).}

Nicola Palazzolo, ${ }^{37}$ discorrendo a respeito do poder discricionário dos pretores e seu papel político no último século da República, afirma que a Lei Aebutia - que oficializou o processo formulário na metade do séc. II a.C. - potencializou o poder dos magistrados judiciários, não só em razão dos novos instrumentos processuais de que dispunham para superar as barreiras do ius civile, mas principalmente por meio da emanação de seus editos.

Através desses instrumentos - notadamente os editos - "a função jurisdicional pretoriana foi se autonomizando cada vez mais em razão de seu poder de imperium, ${ }^{38}$ comum a todos os magistrados que representavam o poder político, e passou a

33 Cf. RICCOBONO, Salvatore. Iurisprudentia. Iurisprudentia. In: NOVISSIMO Digesto Italiano. 3. ed. Torino: Unione Tipografico Editrice Torinese, 1957. v. 9, p. 352.

34 Assim denominado por derivar da atividade do magistrado investido de honores, cuja obra aperfeiçoou e melhorou o direito posto, dando-lhe uma nova visão.

35 Exceptio era um meio de defesa processual concedido pelos pretores, que era inserido na parte acessória da fórmula onde o réu, invocando direito próprio ou alguma determinada circunstancia, paralisava a pretensão do autor.

36 ALVES, José Carlos Moreira. Curso de direito romano, cit., v. 1, p. 78.

37 PALAZZOLO, Nicola. Processo civile e politica giudiziaria nel principato. Torino: G. Giappichelli, 1991. p. 7.

$38 \mathrm{O}$ imperium era o poder de mando, de fazer valer a sua autoridade. Segundo a doutrina, é um poder unitário, distinto da iurisdictio, que era o poder conferido aos magistrados de declarar o direito, e não julgar, exercida 
se caracterizar como uma atividade independente dos outros poderes estaduais, cujo titular era quem fixava os seus próprios limites e critérios de atuação". ${ }^{39}$

A principal característica da experiência romana reside exatamente nessa vinculação entre a função jurisdicional e a função criadora do direito dos pretores, os quais sequer estavam vinculados às próprias regras que criavam, ${ }^{40}$ pois podiam perfeitamente, no curso de seu mandato - que era de um ano - modificar as regras contidas no seu edito perpetuum, ${ }^{41}$ o que foi proibido a partir de 67 a.C., por uma Lei Cornélia, que determinava que o pretor deveria exercer a sua atividade jurisdicional de acordo com as regras estabelecidas em seu edito. ${ }^{42}$

Essas regras tendiam a ser estáveis, pois os novos magistrados, ao assumirem o cargo, incluíam nos seus editos, na parte translaticia, aquelas regras criadas pelos seus antecessores que haviam sido aprovadas na prática, formando assim um corpo estratificado de cases, que eram aplicados em casos futuros.

Desta forma, os pretores, em virtude de seu poder de Imperium criavam o direito, aplicando a justiça ao caso concreto, cuja solução passava a constar dos editos, sendo utilizado para outros casos semelhantes, tornando-se precedentes judiciários.

No entanto, e revelando a flexibilização do direito pretoriano, era sempre possível modificar uma regra, se a experiência demonstrasse a sua iniqüidade.

Duas passagens do Digesto, nos Livros XIX e XXII, Tít. V, frag. 11, de Pompônio, e Tít. V, frag. 13, de Papiniano, respectivamente, confirmam o papel criador dos pretores, na lacuna da lei, atribuindo-lhe a incumbência de criar o direito, in verbis: "supplet praetor in eo quod legi deest" e, "verumtamen, quod legibus omissum est, non omittetur religione judicantium".

Portanto, a lei em Roma, como pura abstração racional, nunca desempenhou função primordial no sistema geral: os usos e costumes que preponderavam no período primitivo foram pouco a pouco cedendo lugar ao Direito jurisdicional-jurisprudencial, pelo crescente reconhecimento da realização da problemática in concreto.

O pretor, "com o seu "ius honorarium", foi sempre o arauto dos imperativos da "aequitas", porque o intérprete do sentimento de justiça do seu tempo. Decidindo por equidade, pôde negar ao indivíduo o direito de intentar ação (denegatio actionis)... Esse é

\footnotetext{
in iure. Assim é, que a iurisdictio derivou do poder de imperium, ambos inicialmente detidos pelo Rex. Portanto, existiam magistrados que detinham a jurisdictio sem imperium ou cum imperium,

39 Cf. PALAZZOLO, Nicola. op. cit., p. 7.

40 Cf. Id. Ibid.

41 O Edito ou era perpetuum ou repentinum. O Edito perpetuum era aquele elaborado para perdurar um ano, e possuía uma parte denominada de translaticia, onde se repetiam as regras criadas pelos pretores antecessores, aprovadas pela prática, e uma parte onde se incluíam novas regras, denominada de pars nova. Havia ainda o edito repentinum, para prever novas situações, não reguladas no edito perpetuum.

42 Cf. PALAZZOLO, Nicola. op. cit., p. 7.
} 
o conteúdo da aequitas no direito clássico: a justiça do caso singular. Por sua inspiração o magistrado pode afastar uma norma geral se esta se mostrar injusta na aplicação a um caso particular". ${ }^{43}$

O poder concedido aos pretores quanto à administração da justiça, a partir da Lex Aebutia, torna-o árbitro do processo, consignando "nas fórmulas, os elementos a serem valorados pelo iudex, para que a decisão corresponda a eqüidade e, por este motivo, "vão se ampliando nos editos o número de normas e meios ordinários e extraordinários de que poderia se servir o pretor na administração da justiça, para que a administração correspondesse sempre às exigências da equidade". ${ }^{44}$

Foi esse direito, de cunho casuístico, de criação pretoriana, que deu impulso ao direito romano, tornando-o um direito erudito: "foi nesse momento que a ciência do direito lançou a sua base mais sólida e começou praticamente a existir, exigindo a elaboração de categorias típicas próprias, através do trabalho criador dos jurisconsultos..., sendo o Direito Romano um Direito doutrinário e jurisprudencial por excelência, porquanto é orientado pelo saber dos jurisconsultos combinado com as decisões dos pretores, ambos atuando em função da experiência". ${ }^{45}$

A cristalização dessa fonte, tão profícua durante a República Romana e primeiros séculos do Principado, se dá em virtude da gradativa absorção de poderes por parte do princeps, rumo ao absolutismo total, quando o direito e a justiça passam a ser atividade exclusivamente estatal e a lei, fonte exclusiva de criação do direito.

Neste ponto, desde a época do imperador Augusto, inicia-se o processo de desvinculação da atividade jurisdicional da atividade política, acentuando-se cada vez mais o tecnicismo dessa função.

Com a oficialização do processo formulário, pela Lex Iulia Iudiciorum Privatorum, abolindo-se em definitivo as legis actiones, deu-se início ao processo de esvaziamento do poder de imperium dos pretores - que, como vimos, havia dado o suporte para a introdução desse novo tipo de processo em Roma - uma vez que passaram a agir não mais em virtude do seu imperium, regulando-se pela lei.

Opera-se assim uma transformação em Roma, iniciada por essa reforma processual instaurada por Augusto, regulando a utilização do processo formulário - que havia nascido do poder de imperium dos pretores - com o objetivo de subtrair ao máximo os poderes dessa magistratura e separar a função jurisdicional do poder político, cujas

\footnotetext{
43 Cf. CHAMON, Ebert. Instituições de direito romano. 3. ed. rev. e aum. Rio de Janeiro: Forense, 1957. p. 34.

44 RICCOBONO, Salvatore. Iurisprudentia. Iurisprudentia. In: NOVISSIMO Digesto Italiano. 3. ed. Torino: Unione Tipografico Editrice Torinese, 1957. p. 352.

45 Id. Ibid. p. 352.

Cf. REALE, Miguel. Lições preliminares de direito, cit., p. 145-146.
} 
funções ainda haviam se mantido unidas durante o primeiro século do principado, indo contra a tradição republicana. ${ }^{46}$

Posteriormente, por ordem do Imperador Adriano, as regras criadas pelos pretores foram compiladas pelo jurisconsulto Sálvio Juliano, na obra denominada Edictum Perpetuum, passando a ter aplicação geral, proibindo-se aos pretores a criação de novas regras - salvo expresso pedido do princeps ou do senado - devendo esses magistrados limitar-se a inserir em seus editos somente aquelas regras que estivessem contidas na referida obra.

A obra de Sálvio Juliano veio consolidar uma situação de fato, posto que em virtude da crescente concentração de poderes nas mãos do Imperador, os pretores não mais exerciam o trabalho criador de outrora.

Desta forma, nos primeiros dois séculos do Principado, o imperador Augusto ainda manteve muito das instituições republicanas, não obstante as reformas a que procedeu. No entanto, a partir de Adriano, e seus sucessores, em virtude do absolutismo crescente, vão desaparecendo por completo as instituições republicanas: as atividades comiciais que, ainda que de forma restrita, se mantinham com o imperador Augusto; as deliberações do senado (senatusconsultus), que se restringe novamente a mero órgão consultivo, o mesmo ocorrendo com as demais fontes do direito e com a atividade jurisdicional.

No início do Principado, ao príncipe não era atribuída função legislativa, embora todas as suas manifestações possuíssem valor normativo, como os rescripta, decreta, edicta e mandata. ${ }^{47}$ Com o imperador Adriano, na esteira dessa nova fase, as manifestações da vontade imperial vão se multiplicando, deixando de ser ocasionais e se institucionalizando.

Com os Severos, as Constituições Imperiais se equiparam a lei, como atesta Ulpiano (D. 1.4.1.1. (Ulp. 1 Inst.): Quodcumque igitur imperator per epistulum et subscriptionem statuit vel cognoscens decrevit vel de plano interlocutus est vel edictio praecepit, legem esse constat: haec sunt quas vulgo constitutiones appellamus, ${ }^{48}$ passando estas à única fonte viva do direito, ao lado da jurisprudência clássica.

46 Cf. PAlaZZOLO, Nicola. Processo civile e politica giudiziaria nel principato. Torino: G. Giappichelli, 1991. p. 28-29. O mesmo autor discorre, amplamente, a respeito do alcance das Leis Júlias, bem como a respeito da diferença entre iudicia legitima e iudicia quae império continentur.

47 As primeiras eram respostas dadas pelo Imperador a consultas formuladas pelas partes ou pelo iudex, dentro de um processo, edicta eram instruções de caráter geral, decreta eram decisões dadas pelo imperador, em algumas causas, decidindo algum apelo ou até mesmo em primeiro grau e mandata eram instruções dadas aos seus funcionários.

48 "Portanto, qualquer coisa que o imperador estabeleça mediante uma epistula ou um subscriptio, ou tenha decretado em juizo ou de forma interlocutória fora do juízo, ou ordenou por meio de um edito, é certo que é lei: estas são aquelas a que vulgarmente chamamos de constituição". Tradução extraída da obra de PALAZZOLO, Nicola. Processo civile e politica giudiziaria nel principato, cit., p. 66. 


\subsection{A decadência do direito judicial como fonte criadora do Direito Romano}

Como vimos, o absolutismo crescente dos imperadores, que se inicia com Adriano, resulta no engessamento da capacidade criadora dos pretores, cujas atividades foram primordiais no desenvolvimento do Direito Romano.

O Ordenamento jurídico em Roma se consolida, a partir do Dominato, em um regime no qual prevalece uma única fonte do direito, a lei, expressa nas Constituições Imperiais, desaparecendo por completo a pluralidade de fontes que predominavam na época clássica.

Após a regulamentação da jurisprudência pela Lei das Citações, ${ }^{49}$ volta-se a preocupação imperial à unificação das fontes do direito, com o intuito de consolidar a aplicação das leis gerais, uniformizando a aplicação do Direito.

Dentro dessa nova mentalidade, dá-se inicio ao trabalho de organização e sistematização das regras jurídicas, tendo sido o Código Teodosiano a primeira compilação oficial do Império.

Essa obra foi promulgada em 15 de fevereiro de 438, e reuniu todas as constituições elaboradas a partir de Constantino, atribuindo-se a ela supremacia sobre as demais fontes da época clássica.

A nova mentalidade teorizante bizantina dá lugar, a partir do século $\mathrm{V}$, ao florescimento de escolas em Constantinopla, voltadas ao ensino de conceitos teóricos, definições, sistematizações, classificações, prevalecendo a preocupação pela abstração, em detrimento dos critérios concretos que norteavam os estudiosos romanos da época clássica. $^{50}$

Foi exatamente por meio dessas escolas que o imperador Justiniano apreendeu juristas e materiais para proceder a sua grande obra de compilação do direito romano clássico.

Neste monumental trabalho de compilação, coordenado por seu ministro Triboniano, Justiniano conserva as antigas fontes do período clássico romano, que passam a ser dotadas de caráter geral, restringindo, no entanto, a sua interpretação, coroando

\footnotetext{
49 Constituição Imperial do ano de 426 d.C., de autoria dos imperadores Theodósio II e Valentiniano III, e que veio a regular a utilização da jurisprudência clássica, conservando a autoridade apenas de alguns jurisconsultos, em todas as questões jurídicas. Essa Constituição, na verdade, criou um verdadeiro tribunal de mortos, uma vez que somente poderiam ser invocados em juízo os escritos de 5 (cinco) jurisconsultos: Gaio, Ulpiano, Paulo e Modestino, bem como as opiniões dos autores citados por qualquer deles, desde que o original fosse trazido a juízo.

50 Nesse sentido, GROSSO, Giuseppe. Lezione di storia del diritto romano, cit., p. 481-482.
} 
a supremacia da lei e adotando a figura de um único legislador-intérprete do direito: o imperador. $^{51}$

A diferente concepção no período pós-clássico da relação entre lei - as Constituições Imperiais - e a interpretação, submetendo esta àquela, foi exatamente uma das causas da decadência da ciência jurídica em Roma e de sua redução ao trabalho sem brilho e modesto das escolas de direito da época.

Contribuiu ainda o fato de que Justiniano pró́be, expressamente, a livre interpretação de sua obra legislativa, nos termos da Constituição Tanta, bem como de outra sua Constituição, de 529, que dispõem: ${ }^{52}$

Nenhum juiz ou árbitro pense ter o dever de seguir as decisões proferidas em consultas que entenda não estarem corretas, e, muito menos, as sentenças dos eminentíssimos prefeitos ou de outros juízes superiores (de fato, se alguma coisa não foi bem decidida, esse erro não deve ser disseminado por outros juízes, devendo-se julgar não com base nos exemplos, mas nas leis), nem mesmo se forem sentenças judiciais proferidas pela respeitadíssima prefeitura ou por qualquer máximo magistrado; determinamos, ao invés, que todos os juízes se deixem guiar pelos caminhos da verdade e da lei e da justiça.

O direito romano-que no seu período de apogeu era um direito eminentemente social, elaborado de acordo com as necessidades da sociedade, e principalmente por aqueles que deveriam dirimir as controvérsias in concreto, os pretores - perde assim o caráter de direito de origem social para assumir aquele de direito que encontra o fundamento de sua validade na vontade do príncipe, segundo a fórmula do Codex (que é uma das quatro partes do Corpus), segundo a qual “quod principi placuit legis habet vogorem”, em que se inspira a outra fórmula, mais explícita ainda, segundo a qual "solus priceps potest facere leges". E no desenvolvimento histórico sucessivo considera-se o direito romano como um direito imposto pelo Estado (ou mais precisamente, pelo Imperador Justiniano). ${ }^{53}$

O triunfo do Cristianismo, que assume o caráter de religião oficial do império, também contribui na transformação do direito em Roma, que passa constantemente a invocar o significado e o valor da piedade e caridade nas suas regras.

51 Cf, Constituição Tanta, 21: “....ambiguum fuerit visum, hoc ad imperiale culmen per iudices referatur et ex auctoritate Augusta menifestetur, cui soli concessum este leges et condere et interpretari”.

52 Cf. ARANGIO RUIZ, Vincenzo. Instituciones de derecho romano, p. 44. e C. 7.45.13, cf. tradução de José Rogério Cruz e Tucci, Perspectiva histórica do precedente judicial como fonte do direito, p. 84. Tese apresentada para Concurso ao cargo de Professor Titular de História do Direito da Faculdade de Direito da Universidade de São Paulo.

53 BOBBIO, Norberto. O positivismo jurídico. São Paulo: Ícone, 1999. p. 7. 
Distancia-se o direito daquele ideal de justiça aristotélico, que preponderava na época clássica romana, assumindo a aequitas o sentido de caridade e benevolência dos imperadores na aplicação da lei. ${ }^{54}$

Encerra-se em definitivo o caráter casuístico do direito romano, cujos princípios jurídicos elaborados na época clássica foram extraídos da profícua experiência dos jurisconsultos e magistrados romanos, rompendo-se com a tradição jurídica romana, avessa às abstrações, cujo sistema elástico e flexível, não poderia ser freado por regras rígidas legais ou costumeiras. ${ }^{55}$

A nova mentalidade que se inicia na época tardo-romana, resulta na "primazia da norma imperial, numa implícita hierarquia das fontes leva-nos ao último século do império clássico, entre os Antoninos e os Severos... A vontade legislativa do príncipe, na sua explicação, projeta de maneira nova os contornos do sistema". ${ }^{56}$

São Paulo, abril de 2009.

Referências

ALVES, José Carlos Moreira. Direito romano. 13. ed. Rio de Janeiro: Forense, 2003. v. 1.

ARANGIO-RUIZ, Vicenzo. Instituciones de derecho romano. Buenos Aires: Ed. Depalma, 1986.

ARISTÓTELES. Ética à Nicomaco. Madrid: Instituto de Estudos Políticos, 1970.

2000.

. A política. Tradução de Roberto Leal Ferreira. 2. ed. 2. tir. São Paulo : Martins Fontes,

BIONDI, Biondo. Istituzioni di diritto romano. 2. ed. rev. e ampl. Milano: Giuffré, 1952.

BOBBIO, Norberto. O positivismo jurídico. São Paulo: Ícone, 1999.

BONFANTE, Pietro. Instituciones de derecho romano. 8. ed. Madrid: Instituto Editorial Reus, 1934.

BRETONE, Mario. História do direito romano. Lisboa: Editorial Estampa, 1988.

CHAMON, Ebert. Instituições de direito romano. 3. ed. rev. e aum. Rio de Janeiro: Forense, 1957.

FERRAZ JR., Tércio Sampaio. Estudos de filosofia do direito. 2. ed. São Paulo: Atlas, 2003..

\footnotetext{
54 Cf. GROSSO, Giuseppe. Lezione di storia del diritto romano. 5. ed. rev. e atual.. Torino: G. Giappichelli, 1965. p. 476-479.

55 Cf. SCHULZ, Fritz. Principios del derecho romano, cit., p. 38.

56 BRETONE, Mario. História do direito romano, cit., p. 268-269.
} 
GAYO. Instituciones. Traducción por Manuel Abellan Velasco-Juan antonio Arias Bonet-Juan Iglesias-Redondo-Jaime Roset Esteve. Madrid: Civitas, 1985.

GROSSO, Giuseppe. Lezione di storia del diritto romano. 5. ed. rev. e atual.. Torino: G. Giappichelli, 1965.

PALAZZOLO, Nicola. Processo civile e política giudiziaria nel principato. Torino: G. Giappichelli, 1991.

PLATÃO. Platão. O político. Trad. Jorge Daleikat e João Cruz Costa. São Paulo: Abril Cultural, 1991. (Os Pensadores).

PORCHAT, Reynaldo. Curso elementar de direito romano. 2. ed. São Paulo: Melhoramentos, 1937. v. 1.

REALE, Miguel. Lições preliminares de direito. 27. ed. São Paulo: Saraiva, 2002.

RICCOBONO, Salvatore. Iurisprudentia. In: NOVISSIMO Digesto Italiano. 3. ed. Torino: Unione Tipografico Editrice Torinese, 1957. v. 9.

SCHULZ, Fritz. Principios del derecho romano. Tradução de Manuel Abellán Velasco. 1. ed. Madrid: Civitas, 1990.

TELLES JÚNIOR, Goffredo. Iniciação na ciência do direito. Ed. Saraiva. São Paulo, 2001.

TUCCI, José Rogério Cruz e. Perspectiva histórica do precedente judicial como fonte do direito. 2003. Tese (Titular de História do Direito) - Faculdade de Direito, Universidade de São Paulo, São Paulo, 2003.

TUCCI, José Rogério Cruz e; AZEVEDO, Luiz Carlos de. Lições de história do processo civil romano. São Paulo: Ed. Revista dos Tribunais, 1996.

VOLTERRA, Eduardo. Instituciones de derecho privado romano. Madrid: Civitas, 1991. 